\title{
PENGEMBANGAN MODUL IPA TERPADU MATERI GERAK MELALUI PENDEKATAN KETERAMPILAN PROSES SAINS PADA PESERTA DIDIK KELAS VIII SMP HIKMAH YAPIS JAYAPURA
}

\author{
ITA RISAHONDUA
}

Guru SMP Hikmah Yapis Jayapura

\begin{abstract}
Research and Development on Learning using IPA module based on science process skill approach aimed at: (1) knowing how to develop learning module of science. (2) to know the feasibility of developing the learning module of science. (3) to know the advantages and disadvantages of IPA learning module. (4) to know the improvement of learning result by using learning module of IPA. The location of this research was conducted in class VIII SMP Hikmah Yapis Jayapura with 30 students. The results of the validity of module validator obtained by $91.42 \%$ with very decent category, the validation of teachers obtained $76.25 \%$ with good category, and the results of large-scale module test of $84.17 \%$ with very good category. To know the increase of result from science process skill done directly with result of average percentage equal to $80,44 \%$ with good category. the result of the average n-gain analysis of class VIII learning result is 0.40 of medium concept concept category, the final analysis result can be concluded that the use of class VIII motion module gives positive impact for the students in learning, so that the science process skill is effectively used in the learning.
\end{abstract}

Keywords: IPA Module, Through Science Process Skills.

\begin{abstract}
Abstrak. Penelitian dan Pengembangan tentang Pembelajaran menggunakan modul IPA berbasis pendekatan keterampilan proses Sains bertujuan yaitu : (1) mengetahui cara pengembangan modul pembelajaran IPA. (2) mengetahui kelayakan dari pengembangan modul pembelajaran IPA. (3) mengetahui kelebihan dan kekurangan modul pembelajaran IPA. (4) mengetahui peningkatan hasil belajar dengan menggunakan modul pembelajaran IPA. Lokasi penelitian ini dilaksanakan di kelas VIII SMP Hikmah Yapis Jayapura dengan jumlah 30 orang peserta didik. Hasil penelitian kelayakan modul dari validator diperoleh sebesar 91,42\% dengan kategori sangat layak, validasi guru diperoleh $76,25 \%$ dengan kategori baik, dan hasil uji coba modul skala luas sebesar $84,17 \%$ dengan kategori sangat baik. Untuk mengetahui peningkatan hasil dari keterampilan proses sains yang dilakukan secara langsung dengan hasil persentase rata-rata sebesar $80,44 \%$ dengan kategori Baik. Hasil analisis n-Gain rata-rata hasil belajar kelas VIII sebesar 0,40 kategori penguasaan konsep sedang, hasil analisis akhir dapat disimpulkan bahwa penggunaan modul gerak kelas VIII memberikan dampak positif bagi peserta didik dalam belajar, sehingga keterampilan proses sains efektif digunakan dalam pembelajaran.
\end{abstract}

Kata Kunci : Modul IPA, Melalui Keterampilan Proses Sains. 
PENDAHULUAN

Mata pelajaran IPA jenjang pendidikan tingkat SMP/MTs sederajat yang berlaku saat ini adalah IPA terpadu, sesuai dengan peraturan Menteri Pendidikan Nasional ( Permendikbud) No. 68 tahun 2013 tentang standar isi pada kurikulum 2013 menyatakan substansi mata pelajaran IPA di SMP/MTs merupakan IPA terpadu, bukan IPA yang terpisahpisah sebagai mata pelajaran Fisika, Biologi, Dan Kimia (Muzari, 2015)

Pembelajaran IPA Terpadu berdasarkan fakta yang ditemukan di lapangan, bahwa di SMP Hikmah Yapis Jayapura belum terlaksana mengajar dengan menggunakan buku atau modul yang belum bersifat terpadu. Modul merupakan salah satu sumber belajar yang digunakan dalam pembelajaran. Modul penting dalam pembelajaran IPA terpadu agar proses belajar mengajar terlaksana secara maksimal (Purwanto, 2007).

Salah satu masalah yang dihadapi di sekolah adalah lemahnya proses pembelajaran terutama pada mata pelajaran IPA. Dalam proses pembelajaran

IPA, anak kurang didorong untuk mengembangkan kemampuan berpikir kreatif. Proses pembelajaran di kelas diarahkan pada kemampuan anak untuk menghafal informasi.
Lemahnya proses pembelajaran mengakibatkan rendahnya hasil belajar peserta didik di sekolah. Keadaan ini juga disebabkan mata pelajaran IPA kurang diminati oleh sebagian besar peserta didik. Rendahnya hasil belajar dalam IPA di sekolah juga disebabkan beberapa faktor di antaranya materi yang kurang menarik, model pembelajaran yang tidak sesuai, dan evaluasi yang kurang tepat. Hal tersebut disebabkan oleh (1) materi pelajaran yang dirasakan peserta didik terlalu banyak dan kurang menarik. (2) model yang dipakai dalam mengajarkan IPA terpusat pada guru, sementara peserta didik cenderung pasif dan tidak mempunyai kesempatan untuk berpikir tentang materi yang disampaikan, hal itu disebabkan waktu yang ada hanya untuk mencatat hal yang di kerjakan gurunya. rendahnya system evaluasi pembelajaran karena hanya ingin menuntaskan materi namun mengabaikan proses untuk mendapatkannya.

Berdasarkan masalah tersebut pencapaian hasil belajar peserta didik kelas VIII pada tahun ajaran 2016/2017 belum membangun kreativitas, keterampilan dan kemampuan bekerja secara ilmiah. Modul yang menarik dapat mengembangkan keterampilan berpikir sains peserta didik. 
Menurut Tawil dkk (2014: 15), menjelaskan bahwa keterampilanketerampilan dasar dari keterampilan proses sains terdiri atas enam keterampilan yaitu mengobservasi, mengklasifikasi, memprediksi, mengukur, menyimpulkan, dan mengomunikasikan. Sesuai pendapat tersebut, setiap peserta didik harus memiliki keterampilan-keterampilan dasar dalam pembelajaran IPA, sehingga keterampilan

proses sains tersebut dikemas dalam modul pembelajaran yang nantinya dapat membantu peserta didik mengembangkan keterampilan proses sainsnya secara mandiri.

Berdasarkan permasalahanpermasalahan yang ditemukan dan fenomena-fenomena permasalahan yang ada maka penulis tertarik melakukan penelitian melalui proses pembelajaran dengan menyediakan bahan ajar IPA terpadu yang dikembangkan berbasis keterampilan proses sains yang dirangkai dalam sebuah penelitian yang berjudul “ Pengembangan Modul IPA Terpadu Melalui Pendekatan Keterampilan Proses Sains Konteks Materi Gerak Pada Peserta didik Kelas VIII SMP Hikmah Yapis Jayapura”.

\section{METODOLOGI PENELITIAN}

Metode dalam penelitian ini merupakan mixed methods research model embedded Sugiyono (2015), Strategi mixed methods embedded konkuren hampir sama dengan model triangulasi konkuren, karena sama-sama mengumpulkan data kualitatif dan kuantitatif dalam waktu yang bersamaan. Membedakannya adalah model ini memiliki metode primer yang memandu proyek dan data sekunder yang memiliki peran pendukung dalam setiap prosedur penelitian.

Metode yang kurang begitu dominan/berperan (baik itu kualitatif atau kuantitatif) ditancapkan (embedded) ke dalam metode yang lebih dominan (kualitatif atau kuantitatif) Mixed method menghasilkan fakta yang lebih komprehensif dalam meneliti masalah penelitian, karena peneliti memiliki kebebasan untuk menggunakan semua alat pengumpul data sesuai dengan jenis data yang dibutuhkan.

Implementasi produk dilaksanakan pada peserta didik kelas VIII SMP Hikmah Yapis Jayapura.

\section{Pengumpulan Data}

1. Uji coba skala kecil

Model eksperimen ini digambarkan pada gambar 1 seperti berikut: 


\section{0}

Gambar 1 Metode eksperimen dengan

Single One Shot Case Study

Keterangan:

$\mathrm{X}=$ Treatment berupa model

$\mathrm{O}=$ Observasi $/$ hasil dari

penerapan model

2. Uji coba skala luas

Menurut Sugiyono (2015), pengujian model yang lebih dilakukan dengan desain one group pretestposttest yang dapat digambarkan pada gambar 2 sebagai berikut:

\section{$\mathrm{O}_{1} \times \mathrm{O}_{2}$}

Gambar 2 Desain eksperimen

uji coba dengan one group pre test post test keterangan:

$$
\begin{aligned}
& \mathrm{O}_{1}=\text { Pre Test } \\
& \mathrm{O}_{2}=\text { Post Test } \\
& \mathrm{X}=\text { Treatment } \text { berupa } \\
& \text { penerapan model }
\end{aligned}
$$

3. Proses pengumpulan data berasal dari hasil penyebaran instrumen yang digunakan. Adapun data- data yang digunakan adalah angket dan test.

\section{Hasil Penelitian dan Pembahasan}

Hasil belajar dalam penelitian ini untuk dilihat dari hasil $n$-Gain yaitu hasil pre test sebelum menggunakan modul dan hasil post test setelah menggunakan modul. Serta hasil keterampilan proses yang diamati selama proses pembelajaran berlangsung. Pengamatan ini bertujuan untuk mengetahui peran modul IPA terpadu terhadap keterampilan proses sains. Dalam keterampilan proses sains siwa dinilai berdasarkan dari 10 indikator yang telah di tentukan antara lain, mengamati mengiferensi, interprestasi, memprediksi, aplikasi konsep,mengklasifikasikan, perencanaan percobaan, pelaksanaan percobaan, menggunakan alat dan bahan serta mengkomunikasikan. Keterampilan proses sains ini dilakukan untuk setiap peserta didik di masing- masing kelompok pada setiap pemebalajaran RPP 1 sampai dengan RPP 3. Penilaian KPS sama dengan penilaian n-Gain, penilaian n-Gain dilakukan untuk setiap peserta didik masing-masing kelompok setiap pembelajaran RPP1, RPP2 dan RPP3.

Adapaun hasil uji n-Gain RPP1 sampai dengan RPP 3 yaitu sebesar 0,49 maka penguasaan konsep dalam kategori sedang, dapat disimpulkan bahwa penggunaan modul gerak untuk kelas VIII memberikan dampak positif bagi peserta didik dalam belajar. Karena adanya modul, peserta didik dapat menguasai konsep gerak. Setelah di uji n-Gain maka akan dilanjutkan dengan uji Keterampilan proses sains pada modul dengan nilai masing-masing 
peserta didik untuk mengetahui peran modul dalam pembelajaran.

a. Penilaian KPS RPP 1

Hasil penilaian KPS RPP 1 di dapatkan data persentase rata-rata aspek mengamati sebesar $98 \%$ dengan kategori sangat baik, mengiferensi $80 \%$, dengan kategori baik, memprediksi 80,83\% dengan kategori baik, aplikasi konsep 80,83\% dengan kategori baik, mengklasifikasikan $89,16 \%$ dengan kategori sangat baik, perencanaan percobaan $90 \%$ dengan kategori sangat baik, pelakasanakan percobaan $86,66 \%$ dengan kategori sangat baik, menggunakan alat bahan $88,33 \%$ dengan kategori sangat baik, mengkomunikasikan $83,33 \%$ dengan kategori baik. Hasil analisis dari beberapa indikator diatas persentase masuk pada kategori baik dan sangat baik.

b. Penilaian KPS RPP 2

Hasil penilaian KPS RPP 2 di dapatkan data persentase rata-rata aspek mengamati sebesar $94,16 \%$ dengan kategori baik, mengiferensi $88 \%$ dengan kategori sangat baik, interprestasi 78,33\% dengan kategori baik, memprediksi $85 \%$ dengan kategori sangat baik, aplikasi konsep 86,66\% dengan kategori sangat baik, perencanaan percobaan $93,33 \%$ dengan kategori sangat baik, pelakasanakan percobaan $91,66 \%$ dengan kategori sangat baik, menggunakan alat bahan 91,66\% dengan kategori sangat baik, mengkomunikasikan $83,33 \%$ dengan kategori sangat baik. Hasil analisis dari beberapa indikator diatas persentase masuk pada kategori baik dan sangat baik.

c. Penilaian KPS RPP 3

Hasil penilaian KPS RPP 3 di dapatkan data persentase rata-rata aspek mengamati sebesar $90 \%$ dengan kategori sangat baik, mengiferensi 80,83\% dengan kategori baik, interprestasi 80,83\% dengan kategori baik, memprediksi $88,33 \%$ dengan kategori sangat baik, aplikasi konsep $80 \%$ dengan kategori baik, mengklasifikasikan $87,50 \%$ dengan kategori sangat baik, perencanaan percobaan $85 \%$ dengan kategori sangat baik, pelakasanakan percobaan $84,16 \%$ dengan kategori sangat baik, menggunakan alat bahan $88,33 \%$ dengan kategori sangat baik, mengkomunikasikan $80 \%$ baik. Hasil analisis dari beberapa indikator diatas persentase masuk pada kategori baik dan sangat baik.

d. Hasil Penilaian rata- rata KPS Per RPP 1,2, dan 3

Hasil keseluruhan rata-rata RPP 1 sebesar 77,67\%, RPP 2 sebesar 79,16\%, RPP 3 sebesar $84,50 \%$. Hal tersebut menyimpulkan hasil persentase rata-rata 
dari setiap RPP dengan kategori baik dan sangat baik.

Berdasarkan hasil rata-rata KPS pada setiap RPP maka dapat di rekapitulasi persentase setiap KPS sebesar $80,44 \%$ maka kategori untuk 3 RPP adalah dengan kategori baik pada peserta didik SMP Hikmah Yapis Jayapura.

\section{SIMPULAN DAN SARAN}

\section{Simpulan}

Berdasarkan hasil analisis dan pembahasan dapat disimpulkan beberapa hal sebagai berikut :

1. Cara pengembangan modul IPA berbasis keterampilan proses sains pada materi gerak untuk kelas VIII SMP Hikmah Yapis Jayapura yaitu perencanaan produk dan desain produk yang meliputi : tujuan dari pembuatan modul, penggunaan modul, dan muatan keterampilan proses sains. Tahap pertama Desain modul di validasi oleh validator materi, tahap kedua revisi desain modul, tahap ketiga setelah direvisi selanjutnya uji coba skala kecil untuk mengetahui keterbacaan modul dan uji coba skala luas untuk mendapatkan data keterampilan proses sains terhadap modul IPA terpadu materi gerak.

2. Modul pembelajaran IPA berbasis keterampilan proses sains pada materi gerak untuk digunakan peserta didik kelas VIII SMP

Hikmah Yapis Jayapura karena diperoleh kelayakan modul dari validator sebesar $91,86 \%$ dengan kategori sangat layak, sedangkan respons guru diperoleh sebesar $76,25 \%$ dengan kategori baik, dan untuk hasil uji coba skala kecil sebesar $84,17 \%$ dengan kategori sangat baik.

3. Kelebihan dan kekurangan modul pembelajaran IPA berbasis keterampilan proses sains adalah:

a. Kelebihan dari pembelajaran menggunakan modul yaitu peserta didik dapat bertanggung jawab terhadap kegiatan belajarnya sendiri dan dapat belajar sesuai dengan tingkat kemampuannya dan guru bisa langsung mengetahui peserta didik yang berhasil dengan yang kurasng berhasil dalam pembelajaran

b. Kekurangan dari pembelajaran menggunakan modul yaitu menentukan disiplin belajar yang tinggi yang mungkin tidak banyak dimiliki sikap tersebut oleh peserta didik.

4. Hasil belajar dalam penelitian ini untuk dilihat dari hasil n-Gain yaitu hasil pre test sebelum menggunakan modul dan hasil post test setelah menggunakan modul 
dan keterampilan proses. Hasil nGain pada peserta didik sebesar 0,49 dengan kategori penguasaan konsep sedang sesuai dengan $r$ hitung lebih besar dari $\mathrm{r}$ tabel 0,3 . Dan KPS yang di dapatkan oleh peserta didik sebesar $80,44 \%$ yang artinya pembelajaran KPS berdampak positif pada peserta didik.

\section{Saran}

Berdasarkan kesimpulan penelitian, saran peneliti sebagai berikut:

1. Perlu penelitian lanjutan melalui pendekatan keterampilan proses sains menggunakan modul dengan subyek penelitian yang lebih banyak sehingga hasil yang di dapatkan lebih valid.

2. Bagi peneliti, perlu dikembangkan lebih lanjut penelitian tentang penyusunan modul IPA terpadu yang lebih berkualitas sehingga dapat digunakan dalam pembelajaran di sekolah.

3. Bagi sekolah, perlu adanya perhatian dan tindak lanjut dari pihak sekolah agar pemanfaatan modul dalam pembelajaran dapat meningkat.

4. Produk modul ini dapat dikembangkan kembali agar modul lebih menarik dan membuat peserta didik lebih kreatif. Tidak hanya modul dengan materi gerak untuk
SMP kelas VIII dengan pendekatan keterampilan proses sains tetapi dapat menggunakan pendekatan lain yang bervariasi.

\section{DAFTAR PUSTAKA}

Muzari I (2015) Pengembangan Modul IPA Terpadu berbasis sets pada tema makanan sehat \& tubuhku untuk meningkatkan hasil belajar siswa(online), (http: // digilib. uns. ac.Id)

Purwanto, dalam sujiono, (2014) Buku Guru Ilmu Pengetahuan Alam Sugiyono, (2014) Metode Penelitian Pendidikan, Bandung, Alfabeta Sugiyono, (2015) Metode Penelitian \& Pengembangan. Bandung;

Alfabeta

Tahwil, Muh, dkk, (2014) dalam Suprihatin (2017) Keterampilanketerampilan Sains dan Implementasi dalam pembelajaran IPA, Makasar, Badan Penerbit UNM

Undang-undang Republik Indonesia No 68 Tahun 2013 Tentang Standar Isi Kurikulum Pendidikan Nasional, Sdm. Data. Kemendikbud.

Go.id/SNP/dokumen/undangundang no 20 tentang-sidiknas. $P d f$ 